\title{
Austenite grain growth behavior and its effects on fracture splitting performance of 36MnVS4 connecting rod for automobile engine
}

\author{
Y. Ji, X. Sun, F. Zhao, C. Zhang, B. Jiang, Y. Liu* \\ School of Materials Science and Engineering, University of Science and Technology Beijing, Beijing 100083, P. R. China
}

Received 4 July 2017, received in revised form 22 October 2017, accepted 21 March 2018

\begin{abstract}
Austenite grain growth behavior and its effects on fracture splitting performance for the steel 36MnVS4 connecting rod are investigated comprehensively by fracture morphology and microstructure analysis. The results show that the fine prior austenite grain causes the unilateral spalling fracture surfaces at the big end bore of the waster connecting rod product. Besides, the austenite grain coarsening temperature with a holding time of $1 \mathrm{~h}$ is $1000^{\circ} \mathrm{C}$. The austenite grain coarsening time is $4 \mathrm{~h}$ at a temperature of $1200^{\circ} \mathrm{C}$ and decreases with the increase of heating temperature. The relationship between austenite grain size and holding time above coarsening time follows a parabolic law. Regarding previous models and experimental results, the growth model of austenite grain in 36MnVS4 steel is established.
\end{abstract}

K e y words: fracture splitting performance, austenite grain, heating temperature, holding time, mathematical model

\section{Introduction}

As an innovative processing technique, fracture splitting technology of connecting rod appeared in the 1990s in Germany and the United States. The body and cap of connecting rod are brittly fractured and then assembled. It has been developed rapidly in recent years because of the advantages of high assembly precision, strong carrying capacity, saving processing procedure and reducing cost. The prior austenite grain size plays an important role in the fracture splitting performance. The uneven and spalling fracture surfaces are beneficial to appear in the process of splitting due to the excessively fine grain, which is detrimental to the assembly precision. Therefore, on the premise of ensuring application performance, the prior austenitic grains should be as coarse as possible for fracture splitting connecting rod $[1,2]$. The growth of austenite grain is affected by alloying elements, heating temperature and holding time $[3,4] .36 \mathrm{MnVS} 4$ steel is a new type of air-cooled forging medium carbon steel which is suitable for the fracture splitting connecting rod of an automobile engine in recent years [5, 6]. There are few types of research concerning the effect of the austenite grain on the fracture splitting performance for the steel $36 \mathrm{MnVS} 4$ connecting rod. Hence, it is necessary to study the austenite grain growth behavior in high temperature, which is of great significance to the control of its microstructure and properties.

In this paper, austenite grain growth behavior and its effects on the fracture splitting performance for the steel $36 \mathrm{MnVS} 4$ connecting rod were studied. The major cause of spalling fracture surfaces for fracture splitting connecting rod was analyzed. Besides, the effect mechanism of heating temperature and holding time on austenite grain growth was discussed. Moreover, a growth model of austenite grain was established. It is believed that data thus obtained would promote the application of air-cooled forging steel and fracture splitting technology in automobile manufacturing.

\section{Existing problems and experimental procedures}

\subsection{Existing problems}

A waster connecting rod product of steel $36 \mathrm{MnVS} 4$

\footnotetext{
*Corresponding author: tel.: +86-010-62333174; e-mail address: lyzh@ustb.edu.cn
} 


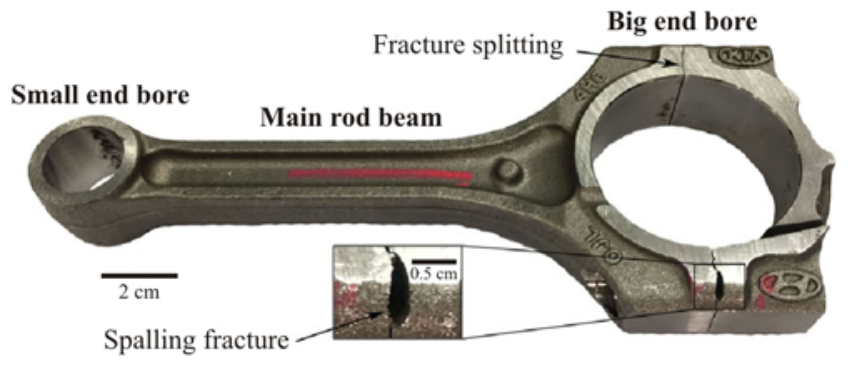

Fig. 1. Photo of the waster connecting rod product.
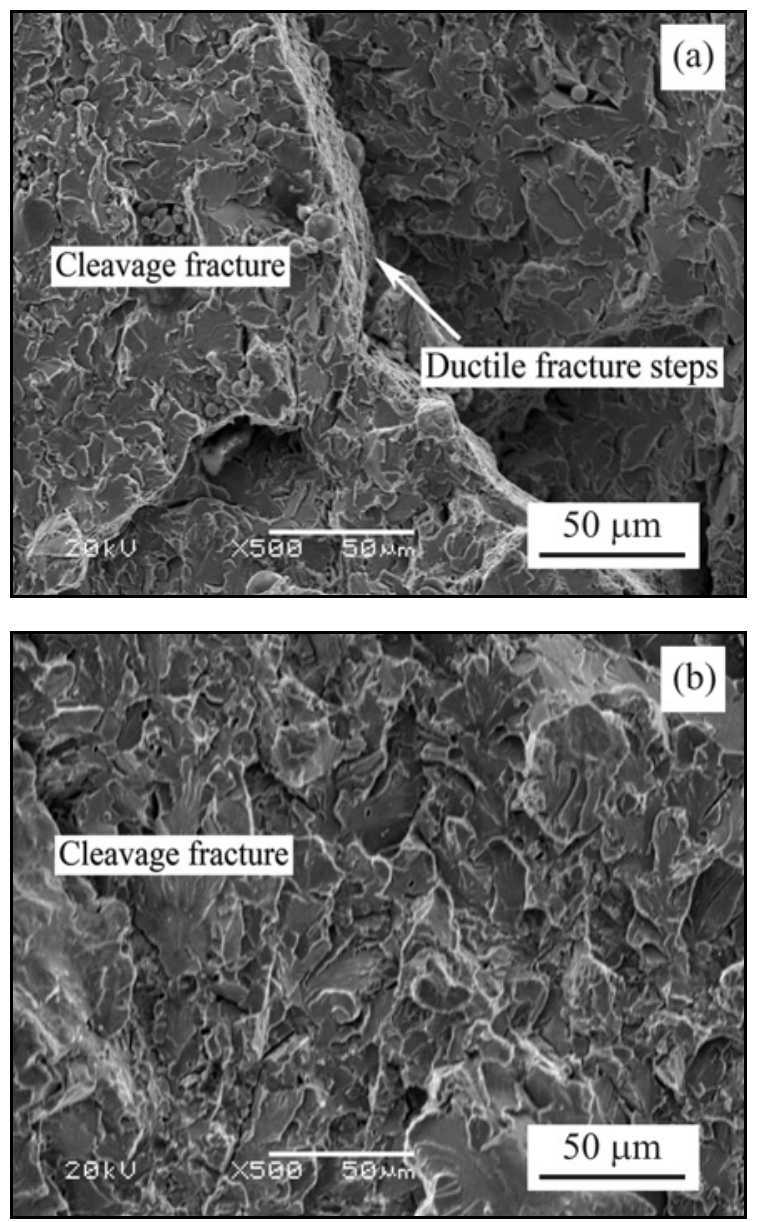

Fig. 2. SEM micrographs of the fracture splitting surface: the spalling fracture side (a) and the qualified side (b).

owing to unilateral spalling fracture surfaces at the big end bore as shown in Fig. 1 was analyzed by fracture morphology and microstructure. The manufacturing process of fracture splitting connecting rod is as follows: $\varnothing 50 \mathrm{~mm}$ bar cutting $\rightarrow$ induction reheating $\rightarrow$ cross wedge rolling $\rightarrow$ die forging $\rightarrow$ trimming and punching $\rightarrow$ hot-bend correction $\rightarrow$ control cooling $\rightarrow$ shot blasting $\rightarrow$ flaw detection $\rightarrow$ machining $\rightarrow$ fracture splitting $\rightarrow$ finish machining. Fracture morphol-
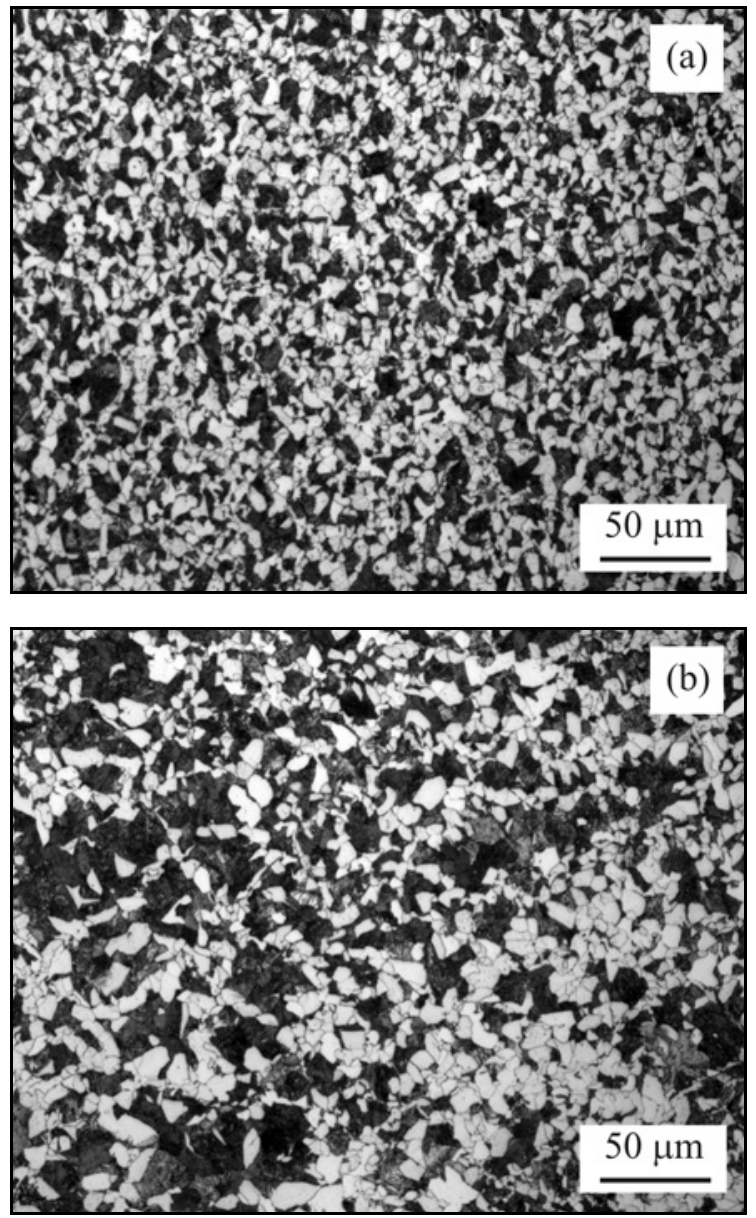

Fig. 3. Optical micrographs showing the microstructure at the big end bore: the spalling fracture side (a) and the qualified side (b).

ogy was analyzed by a JSM-6480LV scanning electron microscope (SEM). The microstructure was observed by Zeiss Axio Scope A1 optical microscope.

SEM micrographs of the fracture splitting surface are shown in Fig. 2. It can be seen from the figures that the fracture surface of the qualified side is even and complete cleavage fracture at the micro level. However, except for the general cleavage fracture, the fracture surface of the spalling fracture side is very uneven and has a multitude of ductile fracture steps.

Optical micrograph of the microstructure at the big end bore is shown in Fig. 3. The microstructure examination revealed the presence of a certain volume of pearlite and equiaxed proeutectoid ferrite. Furthermore, it can be seen from the figures that the sizes of ferrite grains and pearlite colonies of the qualified side are all larger than those of the spalling fracture side. Hence, the austenite grain of the qualified side is coarser than that of the spalling fracture side due to the heredity in the microstructure.

From the fracture morphology and the microstructure results and analysis above, the major cause for 
Table 1. The heating conditions of tested steel

\begin{tabular}{lccccccccccc}
\hline Heating temperature $\left({ }^{\circ} \mathrm{C}\right)$ & 800 & 850 & 900 & 950 & 1000 & 1050 & 1100 & 1150 & 1200 & 1250 \\
\hline Holding time (h) & 1 & 1 & 1 & 1 & 1 & 1 & $0.5,1,2,4$ & $0.5,1,2,4$ & $0.5,1,2,4,6,8,10$ & $0.5,1,2,4$ \\
\hline
\end{tabular}

the waster connecting rod product is the fine prior austenite grain at the big end bore, which is produced during both the connecting rod manufacturing process and the steel hot-rolling process. However, austenite grain size is related to heating temperature and holding time. Consequently, different thermal cycles were carried out to investigate the effects of heating temperature and holding time on the austenite grain growth behavior of the steel $36 \mathrm{MnVS} 4$.

\subsection{Experimental procedures}

The tested steel was obtained from a commercial hot-rolled bar of $50 \mathrm{~mm}$ in diameter, whose original microstructure was ferrite and pearlite. The alloy composition (wt.\%) is $0.36 \mathrm{C}-0.62 \mathrm{Si}-0.98 \mathrm{Mn}-0.028 \mathrm{P}-0.04 \mathrm{~S}-$ $-0.02 \mathrm{Ni}-0.17 \mathrm{Cr}-0.27 \mathrm{~V}-0.0039 \mathrm{Ti}-0.11 \mathrm{Cu}-0.01 \mathrm{Mo}-0.016 \mathrm{~N}$. The specimens were cut from $1 / 2$ radius of the distance center on the cross-section of the bar with $13 \mathrm{~mm} \times 13 \mathrm{~mm} \times 15 \mathrm{~mm}$. They were austenitized in a box type SX-G04133 electric furnace, and the heating conditions are shown in Table 1 . After heating, the specimens were quenched in water immediately. Those quenched specimens were cut apart from the center, and then mechanically ground, polished and etched with a saturated aqueous picric acid solution containing a few drops of detergent for about $2 \mathrm{~min}$ at 50 $60^{\circ} \mathrm{C}$ for the determination of the prior austenite grain sizes. The austenite grains choosing 5 visual fields in every specimen were observed on ZEISS Scope.A1 microscope. The grain size of austenite was measured by using the linear intercept method through Nano Measurer image software, counting more than 400 grains for each specimen to ensure the measurement accuracy, and choosing the mean chord length of austenite grain as a measure of austenite grain size. Besides, the microstructures of those quenched specimens were observed on Quanta FEG 450 thermal field emission environmental scanning electron microscope after mechanically ground, polished and etched with $4 \%$ nitric acid alcohol.

\section{Results and discussion}

\subsection{Effect of heating temperature on the growth of austenite grain}

Figure 4 shows the morphology of austenite grain in $36 \mathrm{MnVS} 4$ steel at different heating temperatures
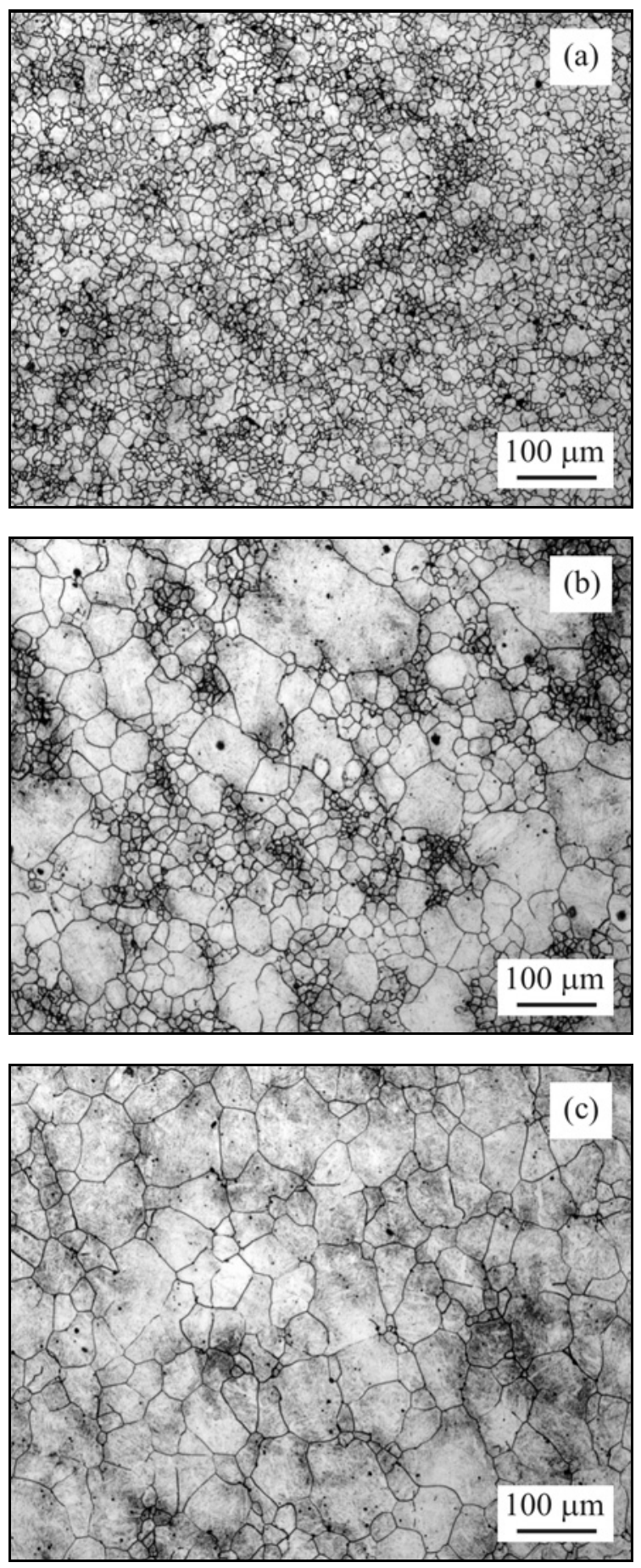

Fig. 4. Effect of the heating temperature on the morphology of austenite grain with holding time of $1 \mathrm{~h}$ : (a) $950^{\circ} \mathrm{C}$; (b) $1000^{\circ} \mathrm{C}$; and (c) $1050^{\circ} \mathrm{C}$. 


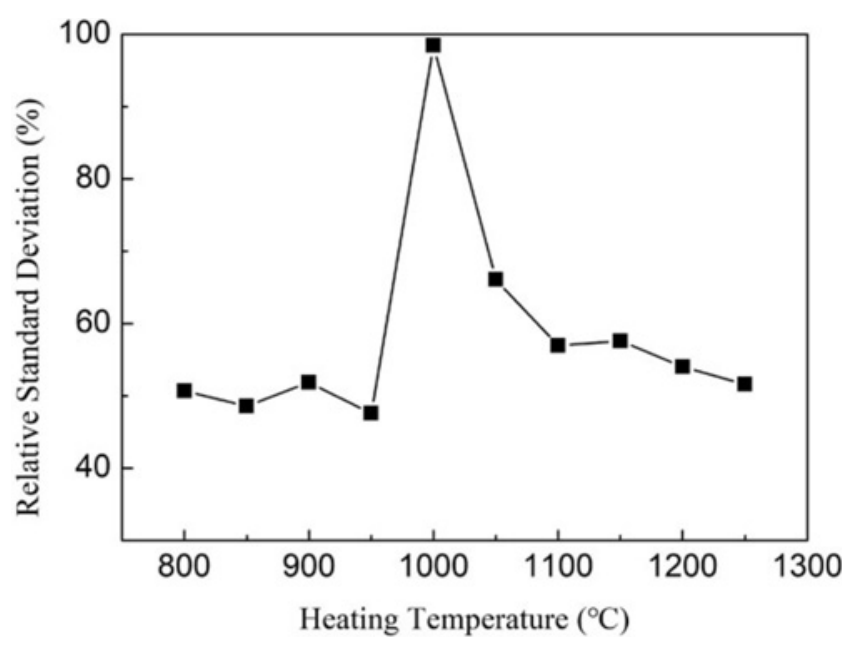

Fig. 5. Effect of the heating temperature on the relative standard deviation of austenite grain size with holding time of $1 \mathrm{~h}$.

and a holding time of $1 \mathrm{~h}$. As seen from Fig. 4, when the heating temperature is $950^{\circ} \mathrm{C}$, the austenite grains are fine and uniform, and the grain boundary is bending. The austenite grains become extremely inhomogeneous, and a certain amount of coarse grains are present at a temperature of $1000^{\circ} \mathrm{C}$. Also, when the heating temperature rises to $1050^{\circ} \mathrm{C}$, the austenite grains grow and become uniform again. The grain boundaries reduce and become flat with the increase of the heating temperature being close to an angle of $120^{\circ}$.

The relative standard deviation can be used to measure the deviation of the single test results from the average value. Thus, the uniformity of austenite grain at different heating temperatures can be expressed by the ratio of the standard deviation and the arithmetic mean of the calculation result (i.e., the relative standard deviation) as shown in Fig. 5. As seen from Fig. 5, at a temperature of $1000^{\circ} \mathrm{C}$, the relative standard deviation of the austenite grain size is the largest, that is, the inhomogeneity of austenite grain increases suddenly at this temperature.

Figure 6 demonstrates the curve of average austenite grain size in $36 \mathrm{MnVS} 4$ steel at different heating temperatures. As seen from Fig. 6, the austenite grains grow up gradually as the heating temperature increases. The average austenite grain size increases from 5.4 to $117.1 \mu \mathrm{m}$, and the ASTM grain size decreases from No. 12.0 to No. 3.5 at a temperature from 800 to $1250^{\circ} \mathrm{C}$. The austenite grain grows up slowly at a heating temperature below $1000^{\circ} \mathrm{C}$, and then the grain size of austenite increases rapidly at a temperature above $1000^{\circ} \mathrm{C}$. Combined with Figs. 1-4, it is known that the austenite grain coarsening temperature with a holding time of $1 \mathrm{~h}$ in $36 \mathrm{MnVS} 4$ steel is $1000^{\circ} \mathrm{C}$.

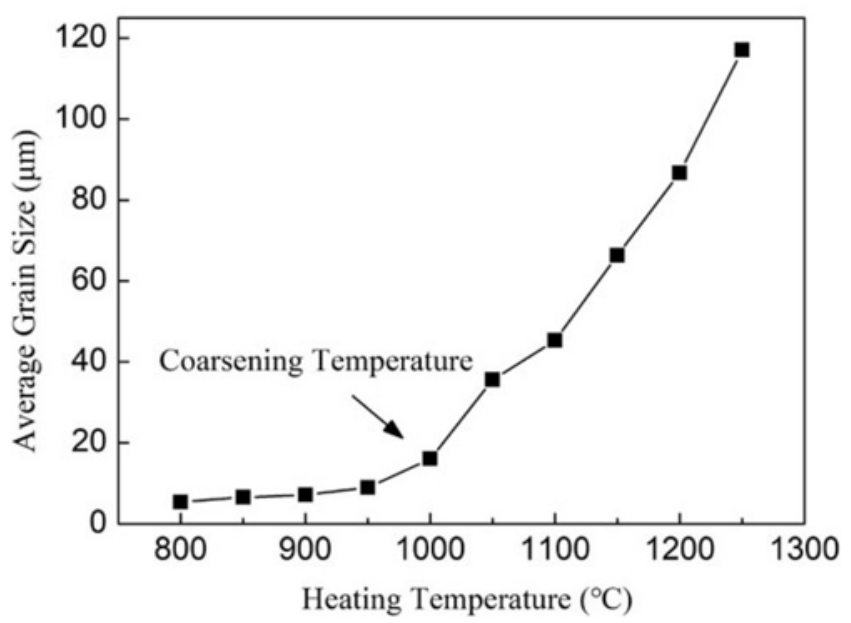

Fig. 6. Effect of the heating temperature on the grain size of austenite with holding time of $1 \mathrm{~h}$.

Figure 7 shows the microstructures of $36 \mathrm{MnVS} 4$ steel at different heating temperatures and a holding time of $1 \mathrm{~h}$. As seen from Fig. 7, there are numerous precipitates which are undissolved carbonitrides containing vanadium in the microstructure at a temperature of $950^{\circ} \mathrm{C}$, while the precipitates are significantly reduced when the heating temperature increased to $1050{ }^{\circ} \mathrm{C}$. Besides, the sizes of particles at $950^{\circ} \mathrm{C}$ are larger than those at $1050^{\circ} \mathrm{C}$. The precipitates have pinning effect on the austenite grain boundary, which prevents the migration of austenite grain boundary and hinders the growth of austenite grain [7-9]. However, most of the precipitates dissolve due to the atomic activity increasing with the increase of heating temperature, which is helpful for the big grain to merge the small one. Thus, the austenite grains grow up slowly below $1000^{\circ} \mathrm{C}$ and rapidly above $1000^{\circ} \mathrm{C}$.

\subsection{Effect of holding time on the growth of austenite grain}

Figure 8 shows the morphology of austenite grain in $36 \mathrm{MnVS} 4$ steel at different holding times and a temperature of $1200^{\circ} \mathrm{C}$. As seen from Fig. 8, many fine austenite grains exist at a holding time of $2-4 \mathrm{~h}$, while the austenite grains become inhomogeneous and coarse grains become larger at a holding time of $4 \mathrm{~h}$. Besides the austenite grains grow up and become uniform with the fine grains decreasing rapidly at a holding time of $6 \mathrm{~h}$, and the morphology of austenite grains tends to stable polygon structure.

Figure 9 demonstrates the curves of average austenite grain size in $36 \mathrm{MnVS} 4$ steel at different holding times and temperatures from 900 to $1250^{\circ} \mathrm{C}$. As seen from Fig. 9, the growth rate of austenite grain above coarsening temperature is faster than that be- 

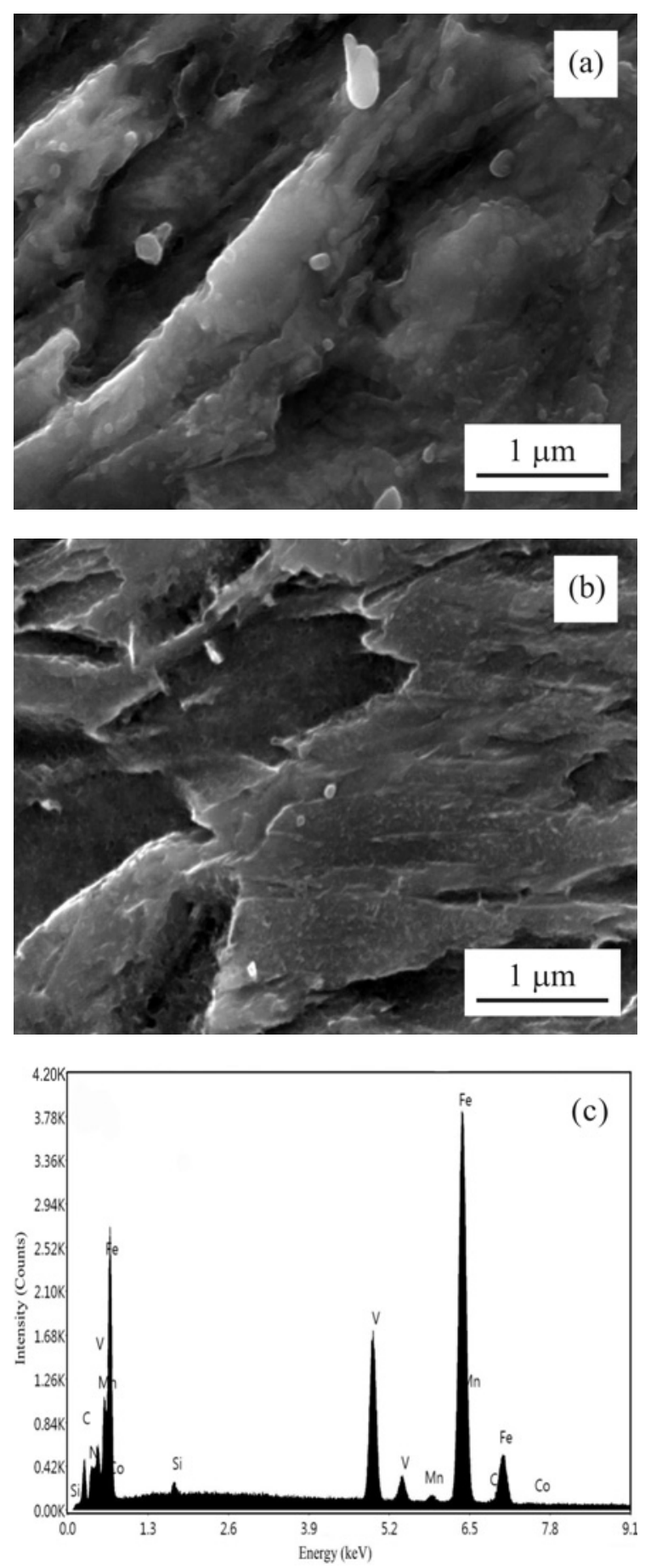

Fig. 7. Effect of the heating temperature on the microstructure and the precipitates with holding time of $1 \mathrm{~h}$ : (a) $950{ }^{\circ} \mathrm{C}$; (b) $1050^{\circ} \mathrm{C}$; (c) the EDS spectrum.

low coarsening temperature with the prolongation of holding time at the same temperature. For example, the austenite grains increase from 7.1 to $7.5 \mu \mathrm{m}$ at $900{ }^{\circ} \mathrm{C}$ and from 46.9 to $49.6 \mu \mathrm{m}$ at $1100^{\circ} \mathrm{C}$ with the prolongation of holding time from 0.5 to $4 \mathrm{~h}$, respectively. This is probably caused by the decrease of pin-
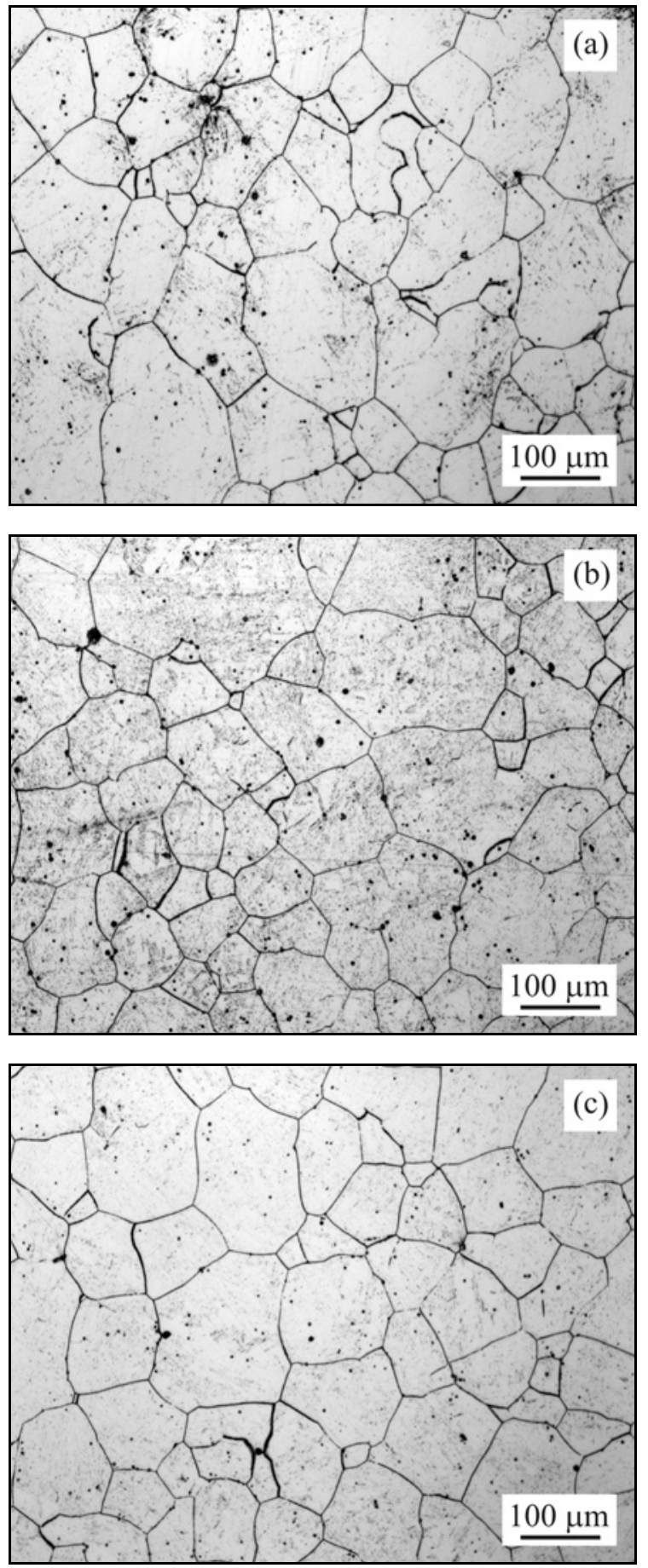

Fig. 8. Effect of the holding time on the morphology of austenite grain at a heating temperature of $1200^{\circ} \mathrm{C}$ : (a) $2 \mathrm{~h}$; (b) $4 \mathrm{~h}$; (c) $6 \mathrm{~h}$.

ning effect and migration resistance of austenite grain boundary due to a large amount of precipitates containing vanadium dissolved above $1000^{\circ} \mathrm{C}$. Also, the austenite grains increase in parabolic law with a holding time from 4 to $10 \mathrm{~h}$ at $1200^{\circ} \mathrm{C}$ and from 0.5 to $4 \mathrm{~h}$ at $1250^{\circ} \mathrm{C}$, and the longer the holding time, the more 


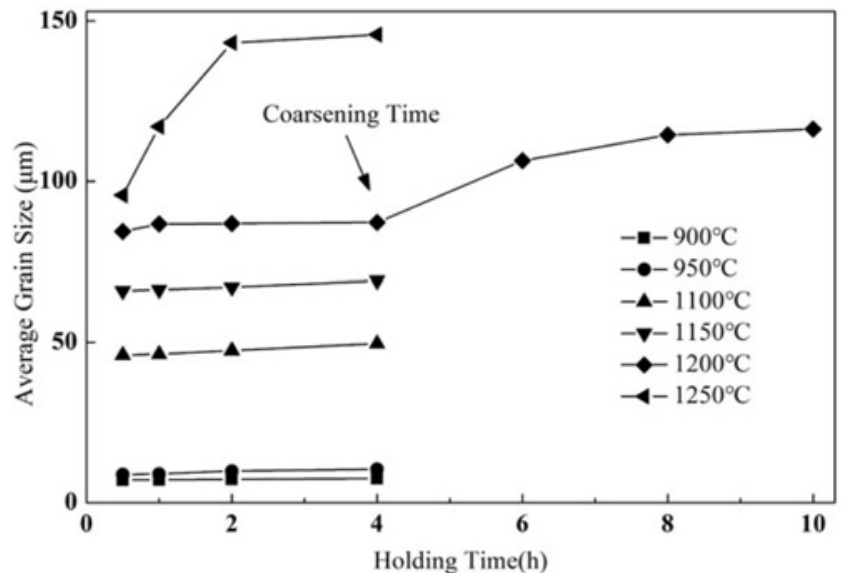

Fig. 9. Effect of the holding time on the morphology of austenite grain at different heating temperatures.

stable the austenite grain is. Therefore, combined with Figs. 5 and 6 , it is known that the austenite grain coarsening time [10] at a temperature of $1200{ }^{\circ} \mathrm{C}$ in $36 \mathrm{MnVS} 4$ steel is $4 \mathrm{~h}$, and that of $1250^{\circ} \mathrm{C}$ is less than
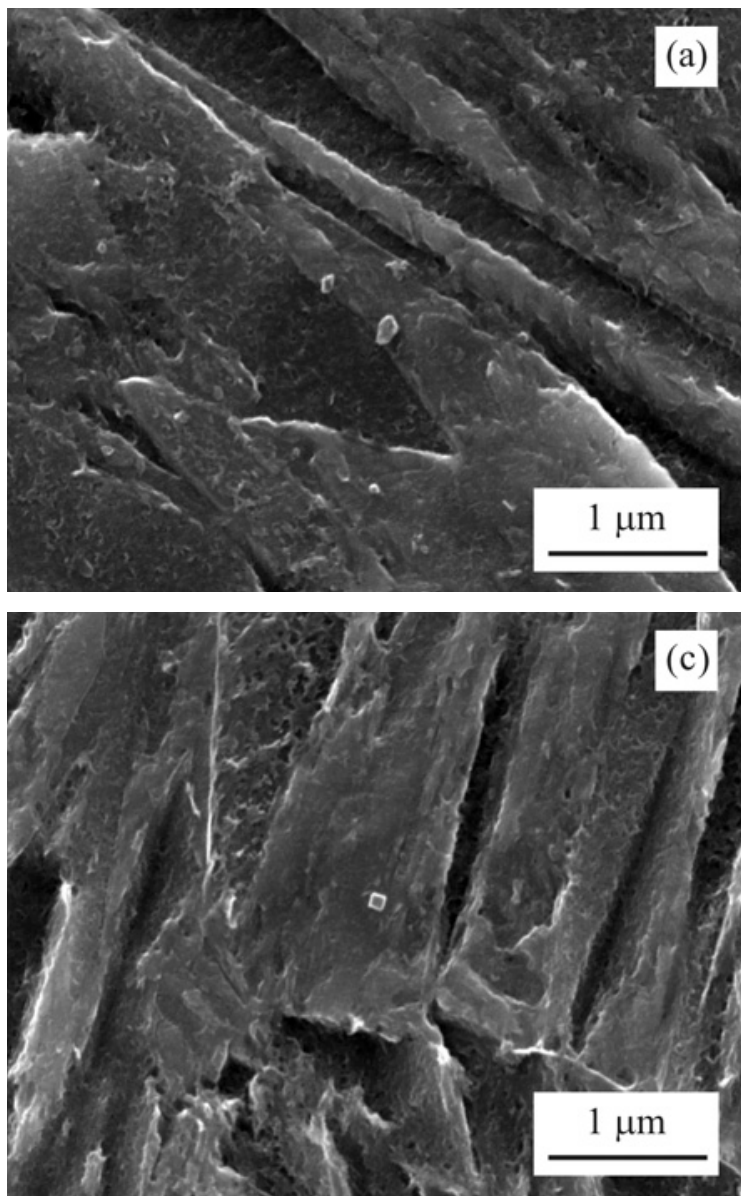

$0.5 \mathrm{~h}$. The austenite grain coarsening time decreases with the increase of heating temperature.

Figure 10 shows the microstructures of $36 \mathrm{MnVS} 4$ steel at different holding times and a temperature of $1200{ }^{\circ} \mathrm{C}$. As seen from Fig. 10, there are some precipitates which are undissolved carbonitrides composite vanadium and titanium in the microstructure at a holding time of $2 \mathrm{~h}$, while the sizes and quantities of precipitates are markedly decreased when the holding time prolongated to $6 \mathrm{~h}$. These particles play a role in pinning the austenite grain boundary and hinder the growth of austenite grain. Thus, the austenite grains grow up slowly below $4 \mathrm{~h}$ and rapidly above $4 \mathrm{~h}$ owing to most of the precipitates dissolved with the prolongation of holding time. Furthermore, the sizes and quantities of precipitates had no obvious changes at holding times from 6 to $10 \mathrm{~h}$ being consistent with the results presented by Baker et al. [11], so that the precipitates play only a minor role in the austenite grain growth in parabolic law for enough holding time. The austenite grains have been adequately grown up, and the driving force of grain growth is weakened for an ample holding time. Consequently, the growth rate of
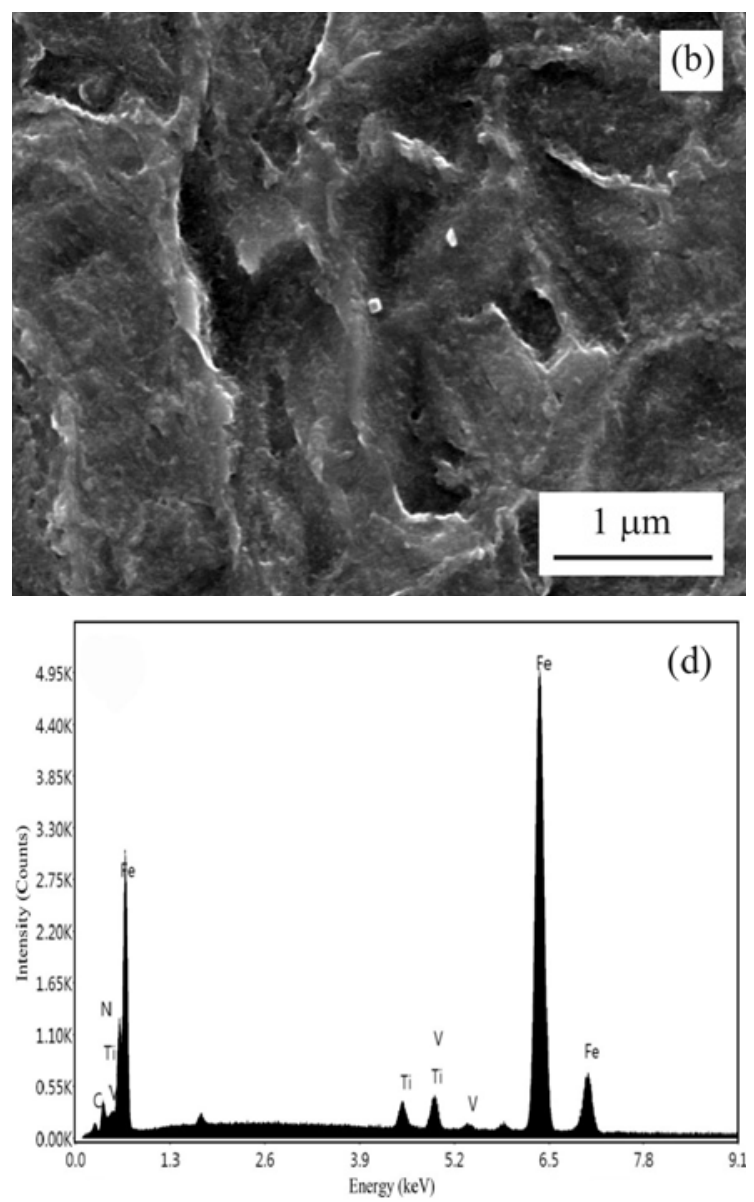

Fig. 10. Effect of the holding time on the microstructure and the EDS of the precipitate at a heating temperature of $1200^{\circ} \mathrm{C}$ : (a) $2 \mathrm{~h}$; (b) $6 \mathrm{~h}$; (c) $10 \mathrm{~h}$; (d) the EDS spectrum. 
austenite grain decreases gradually above coarsening time, and finally, the grain sizes tend to be stable.

Additionally, as seen in Figs. 6 and 9, it is concluded that effect of the holding time on the growth of austenite grain is slighter than that of the heating temperature. It is because the grain growth rate does not increase with the prolongation of holding time at a certain heating temperature after a sharp increase and finally stops to a certain size.

\section{The growth model of austenite grain}

The growth of austenite grain is a physical metallurgy process, which is a kind of interaction of thermal activation, diffusion and interface reaction, and it is mainly manifested as the migration of grain boundaries. After the austenitization of steel during the heating process, the grain boundary of austenite grain migrates under the action of grain growth driving force, which leads to the growth of the grain. Both the total grain boundary area and the free energy of the system decrease with the increase of the average grain size. Thus, the growth of the grain is a spontaneous process, growing up with the increase of temperature or holding time. The growth of austenite grain can be expressed by Arrhenius model [12-14] with Eq. (1):

$$
D=A t^{n} \mathrm{e}^{-Q / R T}
$$

where $D$ is the average austenite grain size $(\mu \mathrm{m}), A$ is the material constant, $t$ is the holding time (s), $n$ is the grain growth index, $Q$ is the activation energy for grain growth $\left(\mathrm{J} \mathrm{mol}^{-1}\right), R$ is the gas constant $(8.314$ $\left.\mathrm{J} \mathrm{mol}^{-1} \mathrm{~K}^{-1}\right), T$ is the absolute heating temperature $(\mathrm{K})$.

As seen from Figs. 4 and 6, the austenite grain size gradually increases with the increase of heating temperature and holding time at a temperature from 800 to $1250^{\circ} \mathrm{C}$ of $36 \mathrm{MnVS} 4$ steel. Therefore, the relationship between grain size, heating temperature and holding time in the range of $800-1250{ }^{\circ} \mathrm{C}$ is fitted. The Eq. (2) is obtained by the logarithm on both sides of Eq. (1):

$$
\ln D=n \ln t+\ln A-Q / R T .
$$

According to Eq. (2), the relationship between $\ln D$ and $\ln t$ is fitted at a constant temperature as shown in Fig. 11. The grain growth index $n$ is a quota to describe the growth rate of grain in the process of isothermal austenite. It can be obtained by the curve of $\ln D$ - $\ln t$. The bigger the $n$ value, the faster the grain grows. As seen from Fig. 11, the $n$ values are $0.029,0.037,0.042,0.051,0.110$ and 0.211 at 900, $950,1100,1150,1200$ and $1250^{\circ} \mathrm{C}$, respectively. The average value of $n$ is about 0.033 at a temperature below coarsening temperature $\left(900\right.$ and $950^{\circ} \mathrm{C}$ ), and

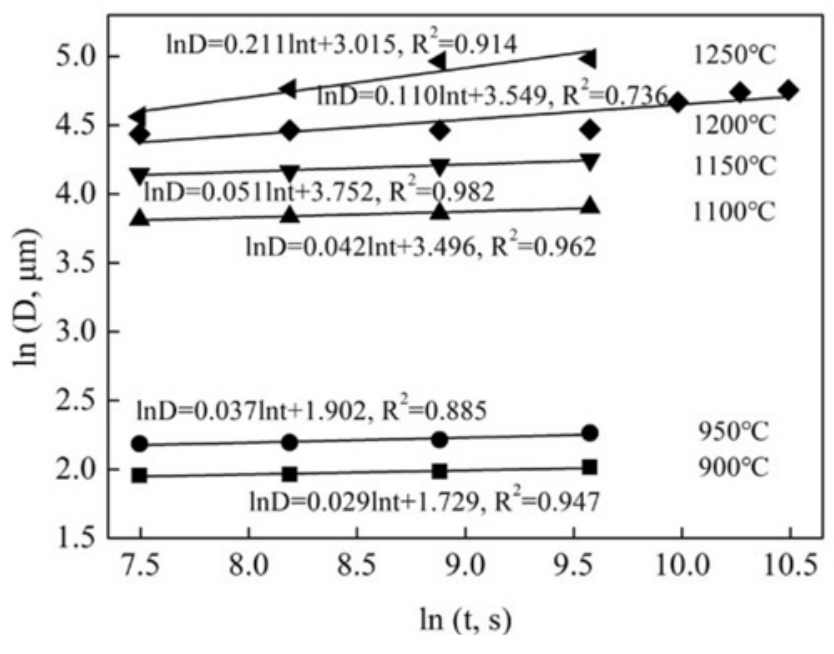

Fig. 11. The relationship between $\ln D$ and $\ln t$ at a constant temperature.

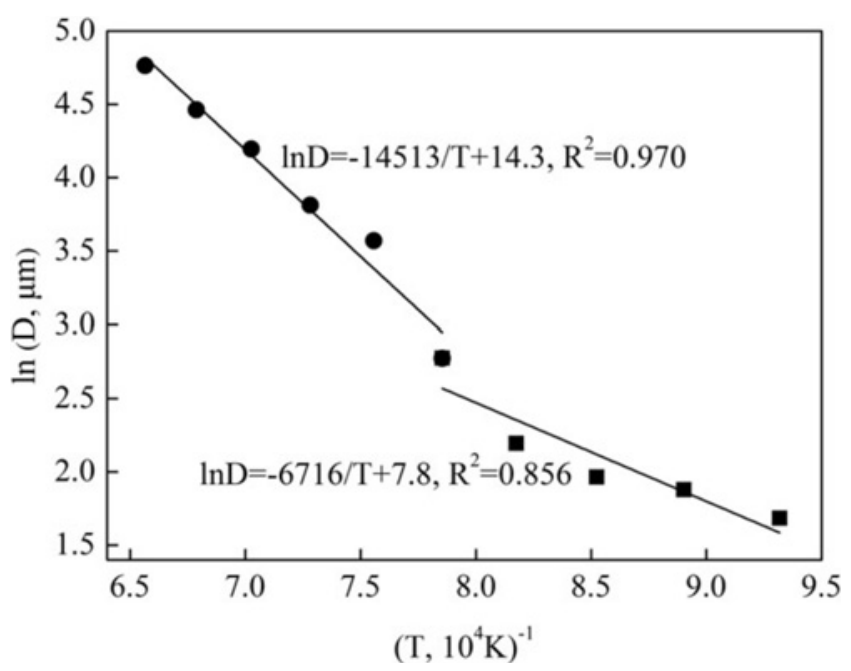

Fig. 12. The relationship between $\ln D$ and $T^{-1}$ at a constant holding time $(1 \mathrm{~h})$.

it is about 0.104 above coarsening temperature (1100, 1150,1200 and $1250^{\circ} \mathrm{C}$ ). The growth rate above coarsening temperature is faster than that below coarsening temperature in the process of isothermal austenite because the grain growth index above coarsening temperature is bigger than that below coarsening temperature, which is consistent with the experimental results shown in Fig. 6.

The relationship between $\ln D$ and $T^{-1}$ is fitted at a constant holding time $(1 \mathrm{~h})$. The activation energy for grain growth $Q$ can be obtained by the curve of $\ln D-T^{-1}$. Hsun $\mathrm{Hu}$ and Rath [15] pointed out that the $Q$ value may change with the temperature when the $n$ value is changed. Thus, the curve of $\ln D-T^{-1}$ is fitted respectively by the data of below and above coarsening temperature as shown in Fig. 12. 
As seen from Fig. 12, the $Q$ values of activation energy for grain boundary at $800-950^{\circ} \mathrm{C}$ and 1050 $1250{ }^{\circ} \mathrm{C}$ are $55837 \mathrm{~J} \mathrm{~mol}^{-1}$ and $120661 \mathrm{~J} \mathrm{~mol}^{-1}$, respectively. The $\ln A$ values are 7.5 and 13.4 , and the $A$ values are $1.81 \times 10^{3}$ and $6.60 \times 10^{5}$, respectively. The growth model of austenite grain in 36MnVS4 steel below and above coarsening temperature can be obtained by the values of $A, n$ and $Q$ with Eqs. (3) and (4), respectively:

$$
\begin{aligned}
& D=1.81 \times 10^{3} t^{0.033} \mathrm{e}^{-55837 / R T}, \\
& D=6.60 \times 10^{5} t^{0.104} \mathrm{e}^{-120661 / R T} .
\end{aligned}
$$

\section{Conclusions}

The following conclusions can be drawn from the present investigation on the austenite grain growth behavior and its effects on the air-cooled forging steel $36 \mathrm{MnVS} 4$ for automobile engine connecting rod.

(1) The major cause of spalling fracture surfaces for fracture splitting connecting rod is the fine prior austenite grain at the big end bore, which is produced during both the connecting rod manufacturing process and the steel hot-rolling process.

(2) The austenite grain coarsening temperature with a holding time of $1 \mathrm{~h}$ is $1000^{\circ} \mathrm{C}$. The austenite grains grow up slowly below $1000^{\circ} \mathrm{C}$ due to the pinning effect of $\mathrm{V}$ particles precipitated during the heating process.

(3) The austenite grain coarsening time is $4 \mathrm{~h}$ at a temperature of $1200^{\circ} \mathrm{C}$ and decreases with the increase of heating temperature. The austenite grains grow up slowly below $4 \mathrm{~h}$ at $1200^{\circ} \mathrm{C}$ due to the pinning effect of composite $\mathrm{V}$ and $\mathrm{Ti}$ particles precipitated during the process of heat preservation. Also, the relationship between austenite grain size and holding time above coarsening time follows a parabolic law.

(4) The austenite grain growth behavior of $36 \mathrm{MnVS} 4$ steel is consistent with the Arrhenius model. The growth model of austenite grain below coarsening temperature is $D=1.81 \times 10^{3} t^{0.033}$ $\mathrm{e}^{-55837 R T}$, and that above coarsening temperature is $D=6.60 \times 10^{5} t^{0.104} \mathrm{e}^{-120661 R T}$.

\section{Acknowledgement}

The authors appreciate the financial support by the Fundamental Research Funds for the Central Universities (No.FRF-TP-16-032A1).

\section{References}

[1] Ceschini, L., Marconi, A., Martini, C., Morri, A., Schino, A. D.: Mater. Des., 45, 2013, p. 171. doi:10.1016/j.matdes.2012.08.063

[2] Zhang, S. S., Li, M. Q., Liu, Y. G., Luo, J., Liu, T. Q.: Mater. Sci. Eng. A, 528, 2011, p. 4967. http://www.sciencedirect.com/science/article/pii/ S0921509311002656

[3] Maropoulos, S., Karagiannis, S., Ridley, N.: Mater. Sci. Eng. A, 483-484, 2008, p. 735. http://www.sciencedirect.com/science/article/pii/ S0921509307009859

[4] Zhang, J., Baker, T. N.: ISIJ Int., 43, 2003, p. 2015. https://www.jstage.jst.go.jp/article/isijinternational 1989/43/12/43_12_2015/_article

[5] Zhang, X. Z., Cai, Q. Z., Zhou, G. F., Chen, Q. F., Xiong, Y. Z.: J. Mater. Sci., 46, 2011, p. 1789. https://link.springer.com/article/10.1007/s10853010-5002-6

[6] Feng, W. D., Pan, J. H.: Adv. Mater. Res., 791-793, 2013, p. 527. https://www.scientific.net/AMR.791793.527

[7] Duan, L. N., Wang, J. M., Liu, Q. Y., Sun, X. J., Cao, J. C.: J. Iron Steel Res. Int., 17, 2010, p. 62. http://www.sciencedirect.com/science/article/pii/ S1006706X1060074X

[8] Sha, Q. Y., Sun, Z. Q.: Mater. Sci. Eng. A, 523, 2009, p. 77. http://www.sciencedirect.com/science/article/ pii/S0921509309006170

[9] Sulák, I., Obrtlík, K., Čelko, L.: Kovove Mater., 54, 2016, p. 471. http://www.kovmat.sav.sk/full.php?rr $=54 \& \mathrm{cc}=6 \& \mathrm{ss}=471$

[10] Lagneborg, R., Hutchinson, B., Siwecki, T., Zajac, S.: The Role of Vanadium in Microalloyed Steels. Kista, Swerea KIMAB 2014.

https://www.researchgate.net/publication/283955 413_Role_of_vanadium_in_microalloyed_steels

[11] Baker, T. N., Li, Y., Wilson, J. A., Craven, A. J., Crowther, D. N.: Mater. Sci. Technol., 20, 2004, p. 720. http://www.tandfonline.com/doi/abs/10.1179/ 026708304225016743

[12] Lee, S. J., Lee, Y. K.: Mater. Des., 29, 2008, p. 1840. http://www.sciencedirect.com/science/article/pii/ S0261306908000344

[13] Pous-Romero, H., Lonardelli, I., Cogswell, D., Bhadeshia, H. K. D. H.: Mater. Sci. Eng. A, 567, 2013, p. 72. http://www.sciencedirect.com/science/article/pii/ S092150931300035X

[14] Wang, B. X., Lian, J. B., Liu, X. H., Wang, G. D.: Kovove Mater., 52, 2014, p. 135. http://www.kovmat. sav.sk/full.php?rr $=52 \& \mathrm{cc}=3 \& \mathrm{ss}=135$

[15] Hu, H., Rath, B. B.: Metall. Trans., 1, 1970, p. 3181. https://link.springer.com/article/10.1007\%2FBF03 $\underline{038435 ? \mathrm{LI}=\text { true }}$ 